\title{
POPULISME, POLITIK PERTAHANAN, DAN PEMIMPIN LOKAL ${ }^{1}$
}

\author{
Muhtar Haboddin \\ Fakultas Ilmu Sosial dan Ilmu Politik, Universitas Brawijaya, Malang \\ email: muhtar_haboddin@ub.ac.id
}

\begin{abstract}
Populism, defence politics, and local leader are interrelated in the study of power. In the framework of maintaining power, local leaders will use populist policies to gain political support from the community. Community support is essential in an electoral democracy. Therefore, the local leaders will respond to the needs of its citizens in the form of populist policy. The ability of local leaders to meet the needs of their citizens is an important part of the working of populist politics. In this populist politics, the beneficiaries are leaders and society. Nevertheless, the beneficiaries are more certainly the local leaders. Why? Is it because local leaders use populism policies as instrumentation in maintaining power? By relying on that question, the choice of populist policy is aimed at two things for the local leaders. First, to gain legitimacy from the community. For local leaders, legitimacy is needed in building political power (Ramlan Surbakti, 1992; 96). It's because the strong legitimacy will make to the local leaders more confident. Second, to strengthen the personal capacity of the local leaders in front of the community and other political forces. By relying on these two goals, the local leaders will have power stronger. Strengthening and maintaining power are the main objective for the local leaders. Therefore, this paper will attempt to present the ability of the local leaders in maintaining his power through the politics of populism at the local level (Vedi R Hadiz, 2017; Willy Purna Samadhi, 2016).
\end{abstract}

Keyword: populism; defence politics; and local leader.

\begin{abstract}
ABSTRAK
Populisme, politik pertahanan, dan pemimpin lokal saling terkait dalam kajian kekuasaan. Dalam kerangka mempertahankan kekuasaan, pemimpin kepala daerah akan menggunakan kebijakan populis untuk mendapatkan dukungan politik dari masyarakat. Dukungan masyarakat sangat penting dalam demokrasi elektoral. Karena itu, kepala daerah akan merespon kebutuhan warganya dalam bentuk kebijakan populis. Kemampuan kepala daerah dalam memenuhi kebutuhan warganya merupakan bagian penting bekerjanya politik populisme. Dalam politik populisme ini yang diuntungkan adalah pemimpin dan masyarakat. Meskipun demikian, yang diuntungkan lebih banyak sudah tentu kepala daerahnya. Mengapa? Apakah karena pemimpin lokal menggunakan kebijakan populisme sebagai instrumentasi dalam mempertahankan kekuasaan? Dengan bersandar pada pertanyaan tersebut, maka pilihan kebijakan populis ini bertujuan untuk dua hal bagi kepala daerah. Pertama, untuk mendapatkan legitimasi dari masyarakat. Bagi kepala daerah, legitimasi diperlukan dalam membangun kekuasaan politik (Ramlan Surbakti, 1992;96) bagi kepala daerah. Sebab, legitimasi yang kuat akan menbuat kepada daerah lebih percaya diri. Kedua, untuk memperkokoh kapasitas personal kepala daerah dihadapan masyarakat dan kekuatan
\end{abstract}

1 Disampaikan dalam Seminar Nasional dalam rangka Dies Natalis FISIP, Universitas Jenderal Soedirman, 16 November 2017. 
politik lainnya. Dengan bersandar pada dua tujuan tersebut, maka kepada daerah akan semakin kuat kekuasaannya. Memperkuat dan mempertahankan kekuasaan merupakan tujuan utama bagi kepala daerah. Karena itu, makalah ini akan berusaha menyajikan kepiwaian kepala daerah dalam mempertahankan kekuasaannya melalui politik populisme di tingkat lokal (Vedi R Hadiz, 2017; Willy Purna Samadhi, 2016).

Kata Kunci: populisme; politik pertahanan; dan pemimpin lokal.

\section{PENDAHULUAN}

Pemimpin populis pada kadar tertentu dianggap sebagai sosok pahlawan. Antony Lee, 2017

Kaum populis menggalang dukungan melalui institusi demokrasi dengan mendekati massa yang dianggap diwakilinya. Margaret Canovan, 2000,808

Dua kutipan di atas saling terkait dalam memberikan makna dan penilaian mengenai kebijakan dan pemimpin populis. Pemimpin populis disenangi masyarakat karena mampu memenuhi kebutuhan masyarakat dalam jangka pendek. Daya tanggap seorang pemimpin untuk mendekati masyarakat dan memenuhi keinginan/kebutuhannya, kemudian 'dianggap sebagai sosok pahlawan', tulis Lee. Mungkin penilaian Lee berlebihan dalam menempatkan sosok pemimpin populis. Tetapi, dalam beberapa kasus jenis pemimpin yang disampaikan Lee menjadi nyata dalam tatakelola pemerintahan. Misalnya, gaya populis Juan Peron di Argentina pada tahun 1940-an atau populisme ala Thaksin Shinawatra di Thailand di tahun 2000-an. Dalam konteks Indonesia, khususnya pemimpin lokal, jenis pemimpin populis juga ditemukan disejumlah wilayah di Tanah Air. Misalnya, Jokowi di Solo dan DKI Jakarta, Risma di Surabaya, Nurdin Abdullah di Bantaeng, Ridwan Kamil di Bandung, dan I Gede Winasa di Jembrana adalah pemimpin yang bekerja untuk rakyat dan mau mendengar suara rakyat.

Kehadiran para pemimpin populis ini boleh jadi bukan karena keinginannya semata, tetapi karena dipaksa oleh situasi politik. Nalar ini dipraktikkan Thaksin dalam rangka mendapatkan dukungan politik dari masyarakat pedesaan. Karena itu, kebijakan populis merupakan instrumen bagi pemimpin politik dalam mempertahankan kekuasaan. Dengan demikian, maka ada keterkaitan antara kebijakan populisme, politik pertahanan, dan pemimpin lokal. Tulisan ini ingin membedah keterkaitan tersebut dalam bingkai kekuasaan. Pilihan kekuasaan didasarkan pada pertimbangan bahwa pemimpin kepala daerah akan menggunakan strategi kebijakan populis untuk mendapatkan dukungan politik dari masyarakat pemilih. Karena itu, pertanyaan adalah bagaimana pemimpin lokal menggunakan kebijakan populis untuk mempertahankan kekuasaan?

\section{MAKNA POPULISME DAN GAYA KEPEMIMPINAN}

Populisme sangat terkait dengan gaya kepemimpinan. Secara konseptual populisme miliki banyak makna. Secara sederhana populisme dimaknai sebagai suara retorika politik, yang menganggap keutamaan dan keabsahan politik terletak pada rakyat. ${ }^{2}$ Jadi, populisme meletakkan rakyat di atas segalanya. Pemahaman ini dilatari gagasan yang mengutamakan

2 Laili Nur Anisah 'Tri Rismaharini: Wajah Pemimpin Populis Indonesia' Caroline Paskarina, Mariatul Asih dan Otto Gusti Madung (ed). Berebut Kontrol Atas Kesejahteraan. (Jogjakarta, Polgov dan PCD, 2015), hlm.99 
kepentingan rakyat. Karena itu, populisme mendapat simpatik dari masyarakat. Dalam bahasa Richard Hofstadter, karena populisme membangun program-program yang membangun masyarakat ${ }^{3}$.

Pendapat lainnya, mengatakan populisme adalah sebuah ideologi yang 'tipis' dalam melihat masyarakat terbagi menjadi dua polarisasi homogen dan antagonistik, yakni orangorang baik yang berhadapan dengan elit korup. ${ }^{4}$ Populisme telah membagi antara orang baik dan orang jahat (elit korup). Orang baik dipersepsikan bisa membantu, menolong, dan menggunakan jabatannya untuk masyarakat. Sebaliknya orang jahat tidak berpihak pada rakyat dan menggunakan jabatannya untuk diri dan keluarganya.

Sejalan dengan itu, populisme biasanya dipimpin oleh sosok karismatik yang menggunakan karisma mereka untuk menarik perhatian publik. Mereka kemudian membangun isu pentingnya mempertahankan hak rakyat kecil yang menyengsarakan rakyat. 5 Memperjuangkan hak rakyat kecil dan keinginan untuk mengangkat derajat manusia menjadikan politik populisme mendapatkan tempat di hati masyarakat. Karena itu, populisme diyakini sebagai gaya politik yang mencakup beragam fenomena yang bisa diungkap. Setidaknya ada empat gaya populisme. Pertama, kediktatoran populis meliputi kasus-kasus dimana tokoh kharismatik punya daya tarik melebihi politisi konvensional, dan mendapat kekuasaan inkonstitusional dengan memberi masyarakat 'makan dan hiburan'. Juan Peron melalui bantuan istinya, Eva mampu membangun pengikut loyal di Argentina pada tahun 1940-an, adalah contoh yang jelas dari praktik kediktatoran populis.

Kedua, demokrasi populis adalah musuh politik representasi dan selalu berusaha mempertahankan sebanyak mungkin kekuasaan di tangan rakyat. Ciri institusionalnya yang khas adalah referendum untuk legislasi yang dihasilkan oleh dewan perwakilan; inisiatif umum, dimana pemberi suara bisa melangkahi majelis dan mengajukan undang-undang untuk ditentukan melalui pemungutan suara dalam referendum; dan lembaga recall, yakni wakil rakyat bisa dipaksa oleh konstituen mereka yang tidak puas untuk melaksanakan pemilihan ekstra sebelum akhir masa tugas mereka.

Ketiga, populisme reaksioner yang menggambarkan para politisi yang bermainmain dengan prasangka massa dalam negara-negara demokrasi untuk melawan pandanganpandangan yang telah dianggap lebih cemerlang dari elit politik. Para politisi yang mendapat popularitas dengan mempermainkan permusuhan etnis atau pandangan sayap kanan mengenai ketertiban umum paling mudah dituding sebagai populisme dalam pengertian ini. Terakhir, populisme kaum politisi adalah politisi yang menghindari komitmen ideologis dan mengklaim berbicara atas nama rakyat secara keseluruhan, bukan untuk faksi tertentu, serta gaya partai 'untuk semua orang' yang prinsipnya tidak banyak, kebijakannya luwes dan siap menerima semua pendatang 6 . Karena itu, populisme merupakan ekspresi dari kehendak umum ${ }^{7}$.

\section{KEBIJAKAN POPULISME DAN POLITIK PERTAHANAN}

Kebijakan populis sangat terkait dengan politik pertahanan kepala daerah. Politik pertahanan yang dimaksud adalah upaya kepala daerah menggunakan kuasanya dalam rangka mendapatkan dukungan politik agar tetap berkuasa. Kekuasaan adalah kemampuan

\footnotetext{
3 Richard Hofstadter, 'Populisme: Nostalgia Agraris' dalam Allen F Davis dan Harold D Woodman (ed). Konflik dan Konsensus. (Jogjakarta, UGM Press, 1991), hlm. 132

${ }^{4}$ Antony Lee, 'Kepahlawanan dalam Intipan Populisme' Kompas, 10 Novermber 2017

${ }^{5}$ Kompas, 8 November 2017

6 Margaret Canovan, 'Populisme' dalam Adam Kuper dan Jessica Kuper (ed). The Social Science Encyclopedia, (Jakarta, RajaGrapindo Persada, 2000), hlm.807

${ }^{7}$ Antony Lee, 'Kepahlawanan., op.cit.
} 
untuk mengerahkan sumberdaya guna mencapai tujuan pemimpin ${ }^{8}$. Salah satu tujuan pemimpin adalah mempertahankan kekuasaannya. Dalam usaha mempertahankan kekuasaannya, maka program-program populis yang bersentuhan dengan masyarakat secara umum perlu disebarkan dan dibagi-bagi. Adapun program populis yang menyangkut kepentingan publik tergambar dari hasil riset Power, Walfare and Democracy (PWD) ${ }^{9}$. Untuk lebih jelasnya bisa dilihat pada grafik.1.

Grafik 1. prioritas program populis

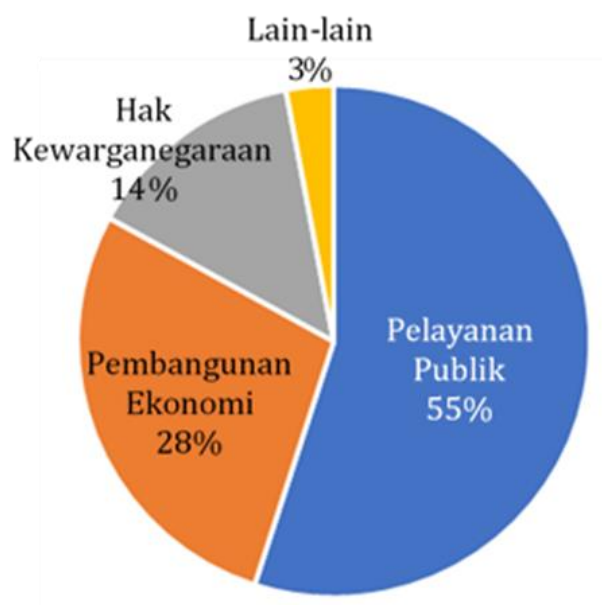

Sumber: PWD, 2014, 10

Pada grafik 1. memperlihatkan bahwa kebijakan populis yang paling penting bagi masyarakat menyangkut isu publik yang berkaitan dengan pelayanan publik yang mencapai 55 persen. Sedangkan isu yang menyangkut pembangunan ekonomi sebanyak 28 persen. Sisanya menyangkut hak kewarganegaraan 14 persen dan lain-lainnya 3 persen. Bila dicermati garfik tersebut, pelayanan publik dan pembangunan ekonomi menempati urutan teratas karena merupakan isu pokok yang bersentuhan dengan masyarakat. Karena bersentuhan langsung dengan kebutuhan masyarakat, maka pemimpin memberikan perhatian khusus pada kebijakan tersebut sebagai cara untuk:

mencari dukungan rakyat melalui kebijakan-kebijakan populis. Strategi ini tidak memerlukan pengorganisasian gerakan rakyat atau dukungan partai-politik yang kuat sebagai instrumen demokrasi, namun lebih bergantung pada upaya individual pemimpin ${ }^{10}$.

Kebijakan populis sangat tergantung pada upaya pemimpin daerah tanpa memerlukan dukungan organisasi massa dan partai politik. Maksudnya, adalah kebijakan populis sengaja dipilih sebagai bentuk keberpihakannya kepada masyarakat. Keberpihakan itu disuarakan sejak masa kampanye hingga menjadi pejabat-sebagaimana ditulis Amalinda:

\footnotetext{
8 Samuel P Huntington, Tertib Politik Dalam Masyarakat Yang Sedang Berubah. (Jakarta, Rajawali Pers, 1983), hlm.219

9 Amalinda Savirani, dkk..Demokrasi di Indonesia: Antara Patronase dan Populisme. (Jogjakarta, UGM-Universitas Oslo, 2014), hlm. 10

10 Amalinda Savirani, 'Negara, Bisnis Yang Terkonsolidasi, dan Pemimpin Populis Baru' dalam Amalinda Savirani dan Olle Tornquist (ed). Reclaiming The State.(Jogjakarta:Polgov dan PCD, 2016), hlm.74
} 
para pemimpin lokal cenderung menggunakan isu-isu populis selama masa kampanye atau pun sedang berkuasa. Misalnya, mereka cenderung mempromosiakan secara terus menerus kebijakan-kebijakan yang berkaitan dengan kesejahteraan publik seperti jaminan kesehatan dan pendidikan gratis ${ }^{11}$.

Jaminan kesehatan gratis dan pendidikan gratis merupakan dua kebijakan paling populis yang diperlukan oleh masyarakat petani, buruh, nelayan, dan kaum miskin kota. Karena menjadi kebutuhan dasar, maka pemimpin lokal berusaha memenuhinya. Namun, dibalik kebijakan populis, pemimpin lokal mengambil manfaat dan keuntungan politik dalam bentuk. Pertama, ingin menegaskan bahwa pemimpin memiliki integritas pribadi yang menyatu dalam ungkapan satu kata dengan perbuatan. Pemimpin dipegang dari ucapannya dan teruji dalam perbuatannya ${ }^{12}$. Karena itu, apa yang menjadi kampanye politiknya akan ditindaklanjuti pada saat menjabat. Biasanya, program-program populis yang ditawarkan pemimpin lokal berkaitan dengan kesejahteraan dan layanan publik.

Kedua, ingin mencitrakan bahwa kekuasaan itu digunakan untuk mensejahterakan masyarakat. Kekuasaan yang mensejahterakan masyarakat merupakan pilihan rasional bagi pemimpin dalam membangun kekuasaan di tingkat lokal. Sebagaimana dikatakan Samuel Huntington bahwa memperluas kesejahteraan keseluruh wilayah merupakan bagian dari pembangunan kekuasaan dan perluasan pengaruh kekuasaan dalam masyarakat ${ }^{13}$. Karena itu mendistribusikan kesejahteraan keseluruh wilayah sangat penting dalam memperkokoh kekuasaan pemimpin. Dengan kata lain, kekuasaan diperuntukkan untuk kebajikan bersama.

Ketiga, kebijakan populis akan menciptakan hubungan yang dekat antara pemimpin dengan masyarakat. Kedekatan antara pemimpin dan masyarakat di bangun melalui kebijakan pro-masyarakat. Pemimpin yang baik selalu merespon kebutuhan masyarakat, memberikan perlindungan, dan memberikan kesejahteraan. Dengan cara ini, maka loyalitas masyarakat akan terbangun secara solid. Jadi, loyalitas masyarakat dibangun melalui kedekatan, memberikan perlindungan dan kesejahteraan. Implikasinya adalah pemimpin mendapatkan pengakuan karena memberikan keteladanan nyata kepada masyarakat.

Keempat, kebijakan populis akan mendapatkan legitimasi dari masyarakat. Legitimasi akan membuka kesempatan yang semakin luas bagi pemimpin untuk tidak hanya memperluas bidang-bidang kesejahteraan dan pelayanan publik, tetapi juga perlu peningkatan kualitas. Peningkatan kualitas berarti peningkatan pengawasan atas penggunaan kewenangan. ${ }^{14}$ Kewenangan merupakan kekuasaan yang memiliki keabsahan dalam menjaga kualitas kesejahteraan dan pelayanan publik yang baik.

\section{POPULISME: BELAJAR DARI DAERAH}

Populisme tumbuh dan berkembang di daerah dalam beberapa tahun terakhir. Catatan sejumlah pengamat menyebutkan bahwa Jokowi di Solo dan I Gede Winasa di Jembrana adalah pemimpin pionir yang mengusung kebijakan populis. Jembrana yang miskin mampu disulap menjadi daerah sejahtera. Pendidikan gartis dan kesehatan gratis dinikmati masyarakat secara luas dan merata. Tidak hanya itu, jembrana juga dikenal pemimpinnya yang berpihak kepada kepentingan masyarakat miskin. Bahkan,

\footnotetext{
${ }^{11}$ Amalinda Savirani, 'Negara, ibid. hlm. 74

12 Djohan Effendi. Pesan-pesan Al-Quran. (Jakarta, Serambi, 2012), hlm. 304

13 Samuel P Huntington, Tertib., op.cit. hlm.224

${ }^{14}$ Ramlan Surbakti, Memahami Ilmu Politik. (Jakarta, Grasindo, 1992), hlm.99
} 
pemimpinnya dikenal secara luas memiliki komitmen dalam mempromosikan kesejahteraan ${ }^{15}$.

Citra pemimpin populis terus bermuncul di daerah. Menariknya adalah mereka menjadi kepala daerah tanpa ada hubungannya dengan Orde Baru. Namun demikian, mereka memiliki karakteristik yang sama. Siapa mereka?

Walikota Surabaya Tri Risma Harini, Walikota Bandung Ridwan Kamil, Bupati Bantaeng Nurdin Abdullah dan Bupati Bojonegero Suyono. Para pemimpin ini merepresentasikan orientasi yang relatif sama yang menganggap kepemimpinan sebagai sebuah kewajiban untuk bekerja demi publik. Mereka juga membangun citra sebagai para pemimpin untuk melayani masyarakat dan tidak terhubung dengan oligarki-oligarki Orde Baru. Keberhasilan mereka dalam membangun politiknya ditopang oleh kredibilitas sendiri ${ }^{16}$.

Ada dua catatan yang bisa ditarik dari kutipan di atas. Pertama, pemimpin lokal bekerja demi rakyat dan melayani masyarakat sepenuh hati. Pemimpin yang melayani merupakan citra yang menempel pada sosok Risma, Kamil, Nurdin, dan Suyono. Kedua, pemimpin lokal ini tumbuh dengan mengandalkan kapasitas individual. Kapasitas individual dioptimalkan dalam rangka memunculkan karakter kepemimpinan kuat, dimana pengaruhnya tidak hanya mendominasi birokrasi daerah, tetapi juga bisa mempengaruhi lembaga legislatif. Karena itu, keberadaan figur yang kuat sangat berperan dalam mentransformasi isu publik ke dalam agenda kebijakan, sehingga pada saat yang sama menguatkan politik yang berbasis individual ${ }^{17}$ atau biasa disebut politik berbasis figur.

Politik yang berbasis figur telah mewarnai politik lokal. Pertama, telah muncul banyak sosok kepala daerah yang mampu menjawab harapan masyarakat. Para kepala daerah hadir dengan sejumlah program-program populitis, inovatif, dan progresif di masa kini. Kedua, menguatnya politik berbasis figur, hadir setelah penerapan sistem pemilihan langsung. Mereka terpilih menjadi pemimpin menjalin hubungan langsung dengan masyarakat. Sosoknya yang dekat dengan masyarakat, lazim disebut pemimpin populis. Pemimpin populis ini juga mampu melakukan inovasi dan pembaharuan pemerintahan daerah. Ketiga, pemimpin populis ini tidak jarang dinilai kontroversial ketika membuat kebijakan, bahkan juga berani berhadapan dengan partai pengusungnya di DPRD ketika kebijakannya tidak disetujui partai politik dan DPRD. Keberanian ini muncul karena kualitas personalnya yang didukung dengan kemampuannya mengelola sumberdaya politik, sosial, dan ekonomi yang demikian besar ${ }^{18}$.

\section{EMPAT TANTANGAN POPULISME DI ARAS LOKAL}

Populisme memberikan warna baru dalam dinamika politik dan kekuasaan di tingkat lokal. Pemimpin lokal dalam mempertahankan kekuasaannya dituntut untuk pandai menggagas program-program populis dan mengontrol kesejahteraan publik. Kemampuan pemimpin populis dalam mempromosikan program populis dan mengontrol kesejahteraan merupakan strategi dalam memperkokoh kekuasaannya. Implikasinya adalah memunculkan personal yang kuat di tingkat lokal dan dalam batas tertentu berani melawan partai politik dan DPRD dengan mengatasnamakan kepentingan rakyat. Atas nama 'rakyat'

15 Sutoro Eko, Dari Daerah Budiman, Menuju Daerah Sejahtera' Mandatory, Edisi 3/Tahun 3/2007. hlm. 60

16 Amalinda Savirani, 'Negara, op.cit. hlm.68-69

17 Caroline Paskarina, Mariatul Asiah, dan Otto Gusti Madung, Berebut Kontrol Atas Kesejahteraan, (Jagjakarta: Polgov dan PCD, 2015), hlm.45

18 Caroline Paskarina, Mariatul Asiah, dan Otto Gusti Madung, Berebut., ibid. hlm. 89-90 
dan 'kepentingan rakyat' bisa menjadi senjata bagi pemimpin populis untuk melawan musuh politiknya.

Karena itu, pemimpin populis perlu diwaspadai karena empat hal. Pertama, jika pemerintahan dikuasai dengan pemimpin populis, dampaknya bisa memundurkan demokrasi ${ }^{19}$. Karena pemimpin populis lebih percaya pada rakyat pemilih sebagai basis kekuasaan ketimbang lembaga demokrasi yang direpresentasikan DPRD. Mengabaikan lembaga DPRD dalam tatakelola pemerintahan daerah sudah tentu tidak dibenarkan. Sebab, kepala daerah dan DPRD merupakan bagian dari penyelenggara pemerintah daerah ${ }^{20}$.

Kedua, pemimpin populis bisa muncul karena lemahnya partai politik. Pemimpinpemimpin yang dikenal masyarakat karena inovasinya, pembaharuan pemerintahan, hingga program populis dalam bentuk pelayanan publik dan kesejahteraan adalah pemimpin yang lahir di luar rahim partai politik. Nurdin Abdullah di Bantaeng berlatarbelakang akademisi dan penguasa. Ridwan Kamil berlatarbelakang tokoh muda aktivis sosial, arsitek tatakota, dan akademisi. Tri Risma adalah birokrat, dan figur Jokowi di Solo dan DKI Jakarta adalah pengusaha. Karena mereka tidak lahir dari rahim partai politik, maka mereka membesarkan dirinya melebihi partai politik. Implikasinya adalah partai politik hanya menjadi instrumen bagi mereka untuk meraih kekuasaan.

Bila hal ini terus dibiarkan, maka marginalisasi peran partai politik semakin membesar dalam ruang politik demokrasi. Fenomena ini tentu sangat membahayakan eksistensi partai politik sebagai tempat lahirnya kaderisasi kepemimpinan. Sepanjangan partai politik gagal melahirkan kader/pemimpin, sudah barang tentu para pemimpin populis akan mengambil manfaat dari kelemahan partai politik.

Ketiga, pemimpin populis akan menghadapi situasi ketidakberlanjutan programprogramnya. Hal ini bisa terjadi karena program-program populis biasanya diciptakan dengan bersandar kemauan pemimpinnya dalam merespon keinginan masyarakat. Program populis biasanya jangka pendek. Jadi, ketika kepala daerah ganti sudah otomatis semua program-program populis juga runtuh seketika. Inilah yang menjadi kelemahan terbesar dari pemimpin populis karena tidak melembagakan program-program populis secara jangka panjang.

Keempat, bila ditarik secara global, politik populis cenderung pada gaya menghasut dan sering menggalang dukungan massa dan rakyat untuk kepentingan politik pemimpin. Catatan Canovan, menyebutkan:

kaum populis menggalang dukungan melalui institusi demokrasi dan politisi dengan mendekati massa yang dianggap diwakilinya. Untuk melakukan itu, mereka memanfaatkan kata rakyat. Di Inggris, rakyat berhadapan dengan faksi-faksi yang bertikai, rakyat berhadapan dengan orang kaya dan kuat, rakyat biasa berhadapan dengan polisi profesional; dan rakyat kita berhadapan dengan orang asing atau etnis minoritas ${ }^{21}$.

Empat tantangan kebijakan populisme membuktikan kemahiran pemimpin populis dalam membangun kekuasaannya. Program-program populis yang selama berkuasa diluncurkan menjadi instrumentasi dalam mempertahankan kekuasaan. Selebihnya bisa dibaca sebagai strategi untuk mendapatkan legitimasi politik karena mampu memberikan kesejahteraan dan pelayanan publik yang baik kepada masyarakat. Legitimasi dan

\footnotetext{
${ }^{19}$ Kompas, 8 Novermber 2017

20 UU 23/2014 Tentang Pemerintahan Daerah, pasal 57

21 Margaret Canovan, 'Populisme' op.cit. hlm. 808
} 
pengakuan dari masyarakat semakin membesarkan citra dirinya sebagai pemimpin pro rakyat dan pemurah. Citra inilah kemudian melekat dalam pemimpin populis di tingkat lokal.

\section{KESIMPULAN}

Pemimpin lokal akan menggunakan kebijakan populis dalam usaha mempertahakan kekuasaan. Dalam mempertahankan kekuasaan membutuhkan kebijakan populis sebagai strategi untuk membangun legitimasi kekuasaannya di mata publik dan politisi di parlemen. Kebijakan populis yang paling dibutuhkan masyarakat adalah kesejahteraan dan pelayanan publik berupa pendidikan dan kesehatan. Dalam rangka memenuhi kebutuhan tersebut, pemimpin lokal akan berusaha memaksimalkan dana pemerintah daerah untuk membiayai program-program tersebut.

Hal ini sengaja dilakukan untuk menunjukkan bahwa pemerintah bekerja untuk rakyat dan kekuasaan digunakan untuk menghasilkan program-program populis. Karena itu, kekuasaan harus mengontrol semua sumberdaya sekaligus mendistribusikannya kepada semua warga tanpa diskriminatif. Pada titik inilah, Goodwyn mengatakan: populisme bersifat ekspansif dan bernafsu. Namun yang terpenting ialah bahwa populisme itu mempertinggi tekad untuk berjuang demi umat manusia. ${ }^{22}$ Dengan demikian beberapa pemimpin populis berusaha mengadakan perubahan yang manusiawi di dalam peri kehidupan masyarakat ${ }^{23}$ lokal. Karena itu, kebijakan populisme akan tetap menjadi pilihan rasional bagi pemimpin lokal yang ingin mempertahankan kekuasaannya.

\section{DAFTAR RUJUKAN}

Anisah, Laili Nur, 'Tri Rismaharini: Wajah Pemimpin Populis Indonesia' Caroline Paskarina, Mariatul Asih dan Otto Gusti Madung (ed).2015 Berebut Kontrol Atas Kesejahteraan. Jogjakarta, Polgov dan PCD.

Canovan, Margaret. 'Populisme' dalam Adam Kuper dan Jessica Kuper (ed).2000. The Social Science Encyclopedia, Jakarta, RajaGrapindo Persada.

Effendi, Djohan. 2012.Pesan-pesan Al-Quran. Jakarta, Serambi.

Eko, Sutoro, 2007. Dari Daerah Budiman, Menuju Daerah Sejahtera' Mandatory, Edisi 3/Tahun 3

Goodwyn, Lawrance, 'Populisme: Janji Demokratis' dalam Allen F Davis dan Harold D Woodman (ed). 1991. Konflik dan Konsensus. Jogjakarta, UGM Press.

Hofstadter, Richard, 'Populisme: Nostalgia Agraris' dalam Allen F Davis dan Harold D Woodman (ed). 1991.Konflik dan Konsensus. Jogjakarta, UGM Press.

Huntington, Samuel P, 1983. Tertib Politik Dalam Masyarakat Yang Sedang Berubah. Jakarta, Rajawali Pers. Kompas, 8 November 2017

Lee, Antony, 2017. 'Kepahlawanan dalam Intipan Populisme' Kompas, 10 Novermber.

Paskarina, Caroline, Mariatul Asiah, dan Otto Gusti Madung, 2015. Berebut Kontrol Atas Kesejahteraan, Jagjakarta: Polgov dan PCD.

Savirani, Amalinda, 'Negara, Bisnis Yang Terkonsolidasi, dan Pemimpin Populis Baru' dalam Amalinda Savirani dan Olle Tornquist (ed).2016. Reclaiming The State.Jogjakarta:Polgov dan PCD

Savirani, Amalinda, dkk.2014.Demokrasi di Indonesia: Antara Patronase dan Populisme. Jogjakarta, UGM-Universitas Oslo

Surbakti, Ramlan, 1992. Memahami Ilmu Politik. Jakarta, Grasindo

UU 23/2014 Tentang Pemerintahan Daerah..

\footnotetext{
22 Lawrance Goodwyn, 'Populisme: Janji Demokratis' dalam Allen F Davis dan Harold D Woodman (ed). Konflik dan Konsensus. (Jogjakarta, UGM Press, 1991), hlm. 159

${ }^{23}$ Richard Hofstadter, 'Populisme:, op.cit hlm. 132
} 